\title{
Students' Learning Styles and Intrinsic Motivation in Learning Mathematics
}

\author{
Vijaya Sengodan ${ }^{1} \&$ Zanaton H. Iksan ${ }^{1}$ \\ ${ }^{1}$ Faculty of Education, Universiti Kebangsaan Malaysia, Selangor, Malaysia \\ Correspondence: Zanaton H. Iksan, Faculty of Education, Universiti Kebangsaan Malaysia, 43600 UKM Bangi, \\ Selangor, Malaysia. Tel: 60-19-600-4627. E-mail: naim@ukm.my
}

Received: September 20, 2012 Accepted: November 7, 2012 Online Published: November 30, 2012

doi:10.5539/ass.v8n16p17

URL: http://dx.doi.org/10.5539/ass.v8n16p17

\begin{abstract}
This study aims to determine the types of learning styles and intrinsic motivation of IKTBNS students and to the relationship between learning styles and intrinsic motivation of students; and difference in learning styles and intrinsic motivation based on gender. This study was carried out by survey research method. The sample consists of 78 students from two departments in National Advanced Youth Skill Training Institute of Sepang (IKTBNS). The Inventory of Learning instrument was used, which postulated four learning styles and three types of intrinsic motivations which are practised by the students in learning mathematics. Data gathered were analyzed descriptively and inferentially using the SPSS package. Result from the descriptive analysis found that the students showed high learning style of surface, while the highly practised intrinsic motivation is self-efficacy as compared to efforts and worry. Inferential analysis results found a significant relationship between hard work learning styles and effort intrinsic motivation. There is a significant difference between genders in organisation learning style as well as genders in effort intrinsic motivation. The implications of this study indicate that motivational factors play an important role in determining the selection of learning styles practised by the students.
\end{abstract}

Keywords: learning styles, intrinsic motivation, mathematics

\section{Introduction}

Academic achievement is closely linked to learning styles and motivation. Several studies have been carried out and have identified that learning styles and motivation differ based on someone's needs and knowledge. Learning styles refer to the method used by an individual to focus and retain new and difficult information. One of the significant challenge a teacher face is to be tolerant and matching the teaching strategies with the students' learning styles in order to recognize learning differences among their student's and also to improve their academic achievement (Tulbure, 2012). Starting from this issue at least two essential questions are asking for an answer: Could a suitable learning styles can improve students mathematics achievement? If the answer is yes, what can be the factor to identify suitable learning style for a student?

In order to answer the first question, a considerable amount of research has confirmed that there is a relationship between learning styles and academic achievement (Dobson, 2010; Indreica, Cazan, \& Truta, 2011; Aziz \& Ahmad, 2008). However, there are studies shows that there is no relationship between learning styles and academic achievement (Aripin, Mahmood, Rohaizad, Yeop, \& Anuar, 2008; Ilias, Rahman, Noor, \& Saidon, 2010). Considering the variety of the existent data, this issue seems to be controversial. Therefore, this study is still needs further investigation. We consider few types of learning styles before select a suitable types of learning style for sample.

Selmes (1987) has reviewed the difficulties in learning from students' and teachers' perspectives. She has discovered five types of learning styles which are deep approach, surface approach, organisation, motivation and hard work to learn mathematics. The study revealed that students are not tied to only one type of learning style.

Variety of learning styles developed by Grasha (2002) through a model called Grasha-Riechmann Student Learning Styles Scales (G-RSLSS). G-RSLSS is based on the behaviors of students from six different types of learning styles, which are competitive, collaborative, avoidant, participant, dependent and independent. According to Grasha (2002), competitive learners like to be the center of attention and receive recognition, 
collaborative learners can work together with teachers and others in the classroom, avoidant learners are uninterested and overwhelmed by things around them, participant learners enjoy going to class and taking part in classroom activities, dependent learners are the ones who need guidance and instruction from teachers or peers on things they have to do, and independent learners are the ones prefer to learn the content themselves. No learning style is better or worse than any other. Each person has different learning styles based on their unique abilities.

In an attempt to answer the second question, we found that students' learning styles are linked tightly either to intrinsic or extrinsic motivation. Few studies determined that students' learning styles have positive relationship with their motivation (N. A. Aziz, Meerah, Halim, \& Osman, 2006; Ilias, Rahman, Noor, \& Saidon, 2010). We also consider the types of motivations before select a suitable type of motivation for this study.

Generally, there are two types of motivation which are external motivation and internal motivation. External motivation arises by external factors such as family, teachers and environment. External motivation can be given in the form of praise, gifts, good grades, incentives and so on. Although, reinforcement is one of the negative ways to motivate someone; it impacts students' behavior positively (Schunk, Pintrich, \& Meece, 2008). On the other hand, intrinsic motivation is encouragement for a person to do something for his/ her self- interest and satisfaction. Intrinsic motivation differs based on students' characteristics (Ryan \& Deci, 2000).

O'Neil, Schacter and Center (1997) have developed the Center for Research on Evaluation, Standard, and Student Testing (CRESST) model and identified three types of intrinsic motivations for problem solving which are effort, self efficacy, and worry. Effort refers to students who have a goal to get good results in a subject even though the given task is not their favorite. They are willing to do extra work on tasks to improve their knowledge (Ball, 1977). Self-efficacy refers to an individual who has self-confidence in his/ her ability and show a brilliant achievement in any given test (Bandura, 1977). Basically, worry refers to negative effects on learning which disturb a person's mind from focusing on relevant issues.

We can summarize that, learning styles and intrinsic motivations are the two main important factors which influence students' achievement in mathematics. There are a lot of researches conducted and identified that high intrinsic motivation with appropriate learning style are able to improve students' achievement in mathematics. The study, conducted by Rashid (2007) stated that there is a significant relationship between students' learning styles and intrinsic motivation. Learning style which is consistent with students' motivation allows a student to explore his/ her potentials and capabilities. Basically, students who were more independent in their thinking were more successful in education.

Mathematics is a core course in Institut Kemahiran Tinggi Belia Negara Sepang (IKTBNS). Therefore, this course is very important and fundamental to other courses because most of the other courses need basic mathematics knowledge. However, it was found that students' mathematics achievement seems to have dropped in recent years. Considering learning styles and motivation are the two factors that can contribute to achievement of students in a course. This study is aimed to explore the types of learning styles and intrinsic motivation of students in learning mathematics; the different learning styles based on gender being pursued; and the relationship between learning styles and intrinsic motivation of students.

\section{Methods and Materials}

This is a quantitative study using survey method. Sample, instrumentation and data analysis method used in this study are illustrated below.

\subsection{Sample}

In this research, simple random sample strategic was used to select sample. Seventy eight (78) respondents were selected from two departments in IKTBNS which are department of Electronics and department of Manufacturing Technology who learned mathematics in this institute. Based on Table 1, it was found that $58.0 \%$ of the students were male and $42.0 \%$ were female. Furthermore, diploma students (60.3\%) show slightly higher proportions compare to certificate students.

Table 1. Profile of the sample

\begin{tabular}{llll}
\hline Variable & Category & N & Percent (\%) \\
\hline Gender & Male & 48 & 61.5 \\
& Female & 30 & 38.5 \\
Program & Certificate & 31 & 39.7 \\
& Diploma & 47 & 60.3 \\
\hline
\end{tabular}




\subsection{Instrumentation}

For this study, the Studying At School Inventory (SASI) by Selmes (1987) was chosen to discover types of learning styles as it focuses on students' learning styles when studying mathematics. Originally, there were 57 questions for five types of learning styles in SASI but only four elements were chosen for this research, which are deep approach, surface approach, hard work and organisation. The fifth element, motivation has been replaced with intrinsic motivation which was used by O'Neil et al. (1997). The selections of intrinsic motivation for this study were effort, self-efficacy and worry. Likert scale 1-5 (1= strongly disagreed and 5=strongly agreed) was used for data collection. A pilot test was conducted on 30 respondents and the Cronbach Alpha analysis showed that the reliability for learning style items were more than alpha $=.675>0.5$. To provide a better understanding of each of the four specific components of learning styles and three components of intrinsic motivations, a description of the component and a sample item for each of the component are provided in Table 2.

Table 2. Selmes's studying at school inventory and O'Neil, Schacter, and center's CRESST model

\begin{tabular}{|c|c|c|c|}
\hline & Component & Characteristic of Learners & Sample item \\
\hline \multirow[t]{4}{*}{$\begin{array}{l}\text { Learning } \\
\text { styles }\end{array}$} & $\begin{array}{l}\text { Deep } \\
\text { approach }\end{array}$ & $\begin{array}{l}\text { Students who are able to put their own view } \\
\text { whenever possible in making notes and } \\
\text { understand the connections between different } \\
\text { aspects and how it links together. }\end{array}$ & $\begin{array}{l}\text { I try to include my own view } \\
\text { whenever possible, in } \\
\text { making notes }\end{array}$ \\
\hline & $\begin{array}{l}\text { Surface } \\
\text { approach }\end{array}$ & $\begin{array}{l}\text { Students who like to memorize while doing } \\
\text { revision and need to be told precisely what to } \\
\text { do and very dependent on teacher and peers. }\end{array}$ & $\begin{array}{l}\text { When reading, I try to } \\
\text { memorise everything }\end{array}$ \\
\hline & Hard work & $\begin{array}{l}\text { Students try to do work as far as possible and } \\
\text { are capable of indentifying their weakness and } \\
\text { correct it. They prefer to do their own notes. }\end{array}$ & $\begin{array}{l}\text { If I do something badly, I try } \\
\text { to work out why, so that I } \\
\text { can do better next time. }\end{array}$ \\
\hline & Organisation & $\begin{array}{l}\text { Students are capable of planning their study } \\
\text { time more effectively, organize their notes } \\
\text { systematically while doing revision. }\end{array}$ & $\begin{array}{l}\text { In written exercises, I write } \\
\text { whatever I think of first. }\end{array}$ \\
\hline \multirow[t]{3}{*}{$\begin{array}{l}\text { Intrinsic } \\
\text { Motivations }\end{array}$} & Effort & $\begin{array}{l}\text { Students who can work very hard to improve } \\
\text { their knowledge. }\end{array}$ & $\begin{array}{l}\text { I work hard to do well even } \\
\text { if I don't like a task. }\end{array}$ \\
\hline & Self Efficacy & $\begin{array}{l}\text { Students who are very confident about their } \\
\text { abilities to understand the most complex } \\
\text { materials presented by the mathematics teacher. }\end{array}$ & $\begin{array}{l}\text { I'm confident that I can do } \\
\text { an excellent job in the } \\
\text { assignments and tests in this } \\
\text { course. }\end{array}$ \\
\hline & Worry & $\begin{array}{l}\text { Students who perform well because of their } \\
\text { anxiety of failing. }\end{array}$ & $\begin{array}{l}\text { Anxiety causes me to be } \\
\text { more focused on my } \\
\text { mathematics lesson. }\end{array}$ \\
\hline
\end{tabular}

\subsection{Data Analyses}

Data were collected through questionnaire which was analyzed descriptively and inferentially in SPSS (version 17). Descriptive analysis is used to interpret students' profile or background information. For Inferential analysis, a t-test was selected to compare mean score of gender and education level based on students' learning style. A Pearson correlation test was also conducted to determine the relationship between learning styles and achievement.

\section{Results}

Each student has a variety of learning styles and intrinsic motivation. The results showed that surface learning style (mean=38.22, $\mathrm{SD}=4.72$ ) is the one used by most of the students and followed by, deep approach ( $m e a n=37.45, \mathrm{SD}=4.04$ ), organisation ( $\min =35.94, \mathrm{SD}=4.38$ ) and finally hard work (min=35.67, $\mathrm{SD}=6.16$ ). Meanwhile, types of intrinsic motivations which are highly used by students in learning mathematics is self-efficacy $(\mathrm{min}=29.07, \mathrm{SD}=4.18$ ), followed by effort (mean=27.13, $\mathrm{SD}=3.68)$ and finally worry (mean=22.43, $\mathrm{SD}=3.46$ ). Table 3 , shows the details for each of the learning styles and intrinsic motivations in learning mathematics. 
Table 3. Types of learning styles and intrinsic motivations

\begin{tabular}{lllll}
\hline Types & & $\mathrm{N}$ & Mean & $\mathrm{SD}$ \\
\hline Learning styles & Deep approach & 78 & 37.45 & 4.04 \\
& Surface approach & 78 & 38.22 & 4.72 \\
& Hard work & 78 & 35.67 & 6.16 \\
& Organisation & 78 & 35.94 & 4.38 \\
Intrinsic Motivations & Effort & 78 & 27.13 & 3.68 \\
& Self-efficacy & 78 & 29.07 & 4.18 \\
& worry & 78 & 22.43 & 3.46 \\
\hline
\end{tabular}

The relationship between learning styles and mathematics score was investigated using Pearson product-moment correlation coefficient. According to Table 4, there is a positive, strong correlation between effort and hard $\operatorname{work}(\mathrm{r}=0.630, \mathrm{n}=78, \mathrm{p}<0.01)$. Overall, effort and self-efficacy have a positive relationship with deep approach, surface approach, hard work and organisation. However, worry has no significant relationship with the four learning styles.

Table 4. Relationship between types of learning styles and intrinsic motivations

\begin{tabular}{llll}
\hline Intrinsic motivations & Effort & Self-Efficacy & Worry \\
\hline Learning Styles & $\mathrm{r}$ & $\mathrm{r}$ & $\mathrm{r}$ \\
Deep approach & $.492^{* *}$ & $.279^{*}$ & .002 \\
Surface approach & $.527^{* *}$ & $.505^{* *}$ & .092 \\
Hard work & $.630^{* *}$ & $.573^{* *}$ & .190 \\
Organisation & $.508^{* *}$ & $.329^{* *}$ & .126 \\
\hline
\end{tabular}

**. Correlation is significant at the 0.01 level (2-tailed)

* Correlation is significant at the 0.05 (2-tailed)

Table 5 displays the scores on the learning styles. The female respondents obtained higher scores in all four components of learning styles; deep approach (mean=38.53, $\mathrm{SD}=3.85$ ), surface approach (mean=38.87, $\mathrm{SD}=4.29$ ), hard work (mean=37.17, $\mathrm{SD}=5.56$ ) and organisation (mean=37.13, $\mathrm{SD}=3.88$ ). There was a significant difference in hard work learning style score $(\mathrm{t}=-1.945, \mathrm{p}=0.43)$ between male and female respondents.

Table 5. T-test of learning styles by gender categories

\begin{tabular}{llllllll}
\hline Learning Styles & Gender & $\mathrm{N}$ & Mean & $\mathrm{SD}$ & $\mathrm{t}$ & $\mathrm{df}$ & $\mathrm{Sig}$ \\
\hline Deep approach & Male & 48 & 36.77 & 4.05 & -1.906 & 76 & .060 \\
& Female & 30 & 38.53 & 3.85 & & & \\
Surface approach & Male & 48 & 37.81 & 4.97 & -.959 & 76 & .341 \\
& Female & 30 & 38.87 & 4.29 & & & \\
Hard work & Male & 48 & 34.73 & 6.38 & -1.723 & 76 & 0.89 \\
& Female & 30 & 37.17 & 5.56 & & & \\
Organisation & Male & 48 & 35.19 & 4.54 & -1.945 & 76 & $0.43^{*}$ \\
& Female & 30 & 37.13 & 3.88 & & & \\
\hline
\end{tabular}

*Indicates significance at the 0.05 level

Table 6 displays the scores on the intrinsic motivations. The male respondents obtained higher scores in all three components of intrinsic motivations; effort (mean=28.85, $\mathrm{SD}=4.22$ ), self-efficacy (mean=27.60, $\mathrm{SD}=4.25$ ), and worry (mean=19.94, $\mathrm{SD}=3.48)$. There was a significant difference in effort intrinsic motivation score $(\mathrm{t}=-2.208$, $\mathrm{p}=0.30$ ) between male and female respondents, favoring males but not for the subscales self-efficacy and worry. 
Table 6. T-test of intrinsic motivation by gender categories

\begin{tabular}{llllllll}
\hline Intrinsic Motivations & Gender & $\mathrm{N}$ & Mean & $\mathrm{SD}$ & $\mathrm{t}$ & $\mathrm{df}$ & $\mathrm{Sig}$ \\
\hline Effort & Male & 48 & 28.85 & 4.22 & -2.208 & 76 & $.030^{*}$ \\
\multirow{3}{*}{ Self-efficacy } & Female & 30 & 26.70 & 3.12 & & & \\
& Male & 48 & 27.60 & 4.25 & .106 & 76 & .916 \\
Worry & Female & 30 & 27.50 & 4.15 & & & \\
& Male & 48 & 19.94 & 3.48 & .749 & 76 & .456 \\
& Female & 30 & 19.33 & 3.45 & & & \\
\hline
\end{tabular}

*Indicates significance at the 0.05 level

\section{Discussion}

The results showed that students are not bound to one learning style but practising a variety of learning styles and intrinsic motivations. Of all the learning styles, surface approach is the most preferred and practised by students in learning mathematics. The findings are further supported by Aziz, Meerah, Halim and Osman (2006) who obtained similar results. Therefore, it can be seen that whether in schools or institutes of higher learning, students are prone to be dependent on others. This scenario can be explained by some of their actions like waiting for instructions from teachers or peers to complete the given tasks as well as developing a tendency for memorizing their notes during revision instead of understanding it.

In addition, this study also showed that students have all kinds of intrinsic motivations. However, self-efficacy is seen to be acquired by most pupils in learning mathematics as compared to effort and worry. This finding contradicts with Yunus, Suraya, and Wan Ali, (2009) study who identified that students have effort in learning mathematics. High skilled students are confident that they can perform well in assignments and exams despite the course being difficult.

Information related to learning styles will enable teachers to identify students' preferable learning style. Therefore, teachers can use various teaching skills, techniques, materials and activities which are specifically suitable to student's learning style (Yahaya, Abd Karim, \& Yahaya, 2003). Furthermore, the findings of this study can help students to know the strengths and weaknesses of their learning styles. By knowing the strength of one's learning style, intrinsic motivation of a student will encourage him/her to develop the suitable learning style for learning mathematics.

Overall, the findings regarding the relationship between learning styles and types of intrinsic motivations showed a strong relationship between effort intrinsic motivation and hard work learning style. A person who has effort will strive to make a good job in the given task despite being not his/her favorite. This character is in line with the characteristic of hard work learning style who can complete a task perfectly even though difficult. Students from this category are capable of working independently and diligently to achieve success. This findings support findings of Aziz et al. (2006) which shows that there is a relationship between intrinsic motivation and deep surface learning style and extrinsic motivation with surface approach learning styles at a low level. Additionally, the study by Ilias, Rahman, Noor, dan Saidon (2010) stated that there is a significant relationship between learning styles and self-efficacy. Meanwhile, worry has no relationship with learning styles as it gives a negative impression that mathematics is a difficult course. This thinking does not encourage students to learn mathematics.

Furthermore, a significant difference in organisation learning style is seen between male and female students. However, no significant difference is observed in deep approach, surface approach and hard work between genders. This is because female students are more discipline and systematic in organizing their notes and planning their answers during exam. They also prefer to make their own notes when doing revision. Study by Aziz et al. (2006) also indicates that there was a significant difference in organized learning styles between genders.

Finally, a significant difference in effort intrinsic motivation occurs between male and female students. However, there is no significant difference in self-efficacy and worry between male and female students. This findings also confirms conclusive findings from previous researches (Tella, 2007) show that there is significant difference in motivation exist between male and female students. Mean score for male students seems to be higher than female students. This shows that male students are willing to do extra work to improve their knowledge and willing to work hard on a task which they dislike. 


\section{Conclusion}

Based on the results, it can be concluded that students have more than one learning style and intrinsic motivation. It is also cleared that, learning styles do have relationship with intrinsic motivations. The results of this study can provide useful information for improving the teaching and learning process of teachers and students. It is important for a teacher to be aware of classes containing students where specific learning styles vary.

Implication of this study indicates that intrinsic motivation plays an important role in the selection of learning styles practised by students. Furthermore, this will help to make teaching and learning processes run smoothly and effectively. Identifying students' learning styles and types of intrinsic motivation early in their academic career would be alert the student to his or her potential academic weakness and will teach those mechanisms by which to cope and/or adapt with their ability.

It is suggested that, the institute has to organize seminars and courses to help students to get to know different types of learning styles and give them the preference to choose the most suitable style to learn mathematics. Teachers also have to plan and implement activities based on students' learning styles to encourage students to effectively participate in the classroom. Selection of appropriate learning style can increase students' motivation. Other than that, funding for smaller classes or more content training will help to increase students intrinsic motivation because students get chance to work with people who have similar learning style with them (Ricks, 2010). Furthermore, student feel motivated when the content is simplified based on their cognitive level. However, more research on this topic needs to be undertaken to understand the relationship between learning style preferences and motivation in teaching and learning process. Other than that a research should be conducted about teaching styles and students motivation too as teachers playing an important role in motivating students.

\section{References}

Aripin, R., Mahmood, Z., Rohaizad, R., Yeop, U., \& Anuar, M. (2008). Students' Learning Styles And Academic Performance. 22nd Annual SAS Malaysia Forum, Kuala Lumpur Convention Center, 15th July. Retrieved February 25, 2011, from http://www.sas.com/offices/asiapacific/malaysia/academic/2008_sum_paper/RasimahZurina.pdf

Aziz, M. N. A., \& Ahmad, N. S. (2008). Kemahiran Belajar dan Hubungannya Dengan Pencapaian Akademik: Kajian di Daerah Kerian, Perak. Jurnal Pendidik dan Pendidikan, 23, 29-47. Retrieved March 6, 2011, from http://web.usm.my/education/publication/KEMAHIRAN\%20BELAJAR_abstract.pdf

Aziz, N. A., Meerah, T. S. M., Halim, L., \& Osman, K. (2006). Hubungan antara motivasi, gaya pembelajaran dengan pencapaian matematik tambahan pelajar tingkatan 4. Jurnal Pendidikan Malaysia, 31, 123-141. Retrieved February 11, 2011, from http://pkukmweb.ukm.my/penerbit/jurnal_pdf/jpend31_09.pdf

Ball, S. (1977). Motivation in Education. Academic Press, Inc. (London) Ltd.

Bandura, A. (1977). Social Learning Theory. Englewood Cliffs, NJ: Prentice Hall.

Dobson, J. L. (2010). A comparison between learning style preferences and sex, status, and course performance. Advance in Physiology Education, 34, 197-204. Retrieved January 17, 2012, from http://advan.physiology.org/content/34/4/197.full.pdf+html; http://dx.doi.org/10.1152/advan.00078.2010

Grasha, A. F. (2002). Teaching with Style. Alliance Publishers.

Ilias, K., Rahman, R. A., Noor, M. M., \& Saidon, N. A. (2010). Pengaruh Gaya Pembelajaran Terhadap Motivasi dan Pencapaian Akademik Pelajar Pra Ijazah Sarjana Muda Perguruan Institut Pendidikan Guru Kampus Ipoh. Jurnal Penyelidikan Dedikasi, 2, 141-153.

Indreica, E.-S., Cazan, A.-M., \& Truta, C. (2011). Effects of learning styles and time management on academic achievement. Procedia-Social and Behavioral Sciences, 30, 1096-1102. http://dx.doi.org/10.1016/j.sbspro.2011.10.214

O'Neil, H. F., Schacter, J., \& Center, E. R. I. (1997). Test specifications for problem-solving assessment. Retrieved October 29, 2011, from http://www.cse.ucla.edu/products/reports/TECH463.PDF

Rashid, R. B. (2007). Hubungan Antara Gaya Pembelajaran Dengan Motivasi Dalam Kalangan Pelajar Di Sebuah Sekolah Menengah Luar Bandar, Sabah.

Ricks, T. E. (2010). Mathematics is motivating. The Mathematics Educator, 19(2), 2-9.

Ryan, R. M., \& Deci, E. L. (2000). Intrinsic and extrinsic motivations: Classic definitions and new directions. Contemporary educational psychology, 25(1), 54-67. http://dx.doi.org/10.1006/ceps.1999.1020 
Schunk, D. H., Pintrich, P. R., \& Meece, J. L. (2008). Motivation in Education: Theory, Research, and Applications (Vol. 3). Pearson Education.

Selmes, I. (1987). Improving study skills: Changing perspective in education. Hodder a. Stoughton.

Tella, A. (2007). The impact of motivation on student's academic achievement and learning outcomes in mathematics among secondary school students in Nigeria. Eurasia Journal of Mathematics, Science \& Technology Education, 3(2), 149-156. Retrieved February 25, 2011, from http://www.ejmste.com/v3n2/EJMSTE_v3n2_Tella.pdf

Tulbure, C. (2012). Learning styles, teaching strategies and academic achievement in higher education: A cross-sectional investigation. Procedia-Social and Behavioral Sciences, 33, 398-402. http://dx.doi.org/10.1016/j.sbspro.2012.01.151

Yahaya, A., Abd Karim, S., \& Yahaya, N. (2003). Hubungan Gaya Pembelajaran Dengan Pencapaian Akademik Pelajar Di Tingkatan Empat Sekolah Menengah Teknik N. Sembilan. National Seminar Memperkasakan Sistem Pendidikan, Puteri Pan-Pacific, Johore Bahru, 19-21 october 2003. Retrieved January 17, 2012, from http://eprints.utm.my/2243/1/AziziYahaya_Hubungan_Gaya_Pembelajaran_dengan_Pencapaian.pdf

Yunus, M., Suraya, A., \& Wan Ali, W. Z. (2009). Motivation in the Learning of Mathematics. European Journal of Social Sciences, 7(4), 93-101. Retrieved March 21, 2011, from http://www.eurojournals.com/ejss_7_4_10.pdf 